\title{
UJI ANTIDIABETIK EKSTRAK ETANOL BUNGA PEPAYA (Carica papaya L.) TERHADAP TIKUS PUTIH JANTAN (Rattus norvegicus) YANG DIINDUKSI ALOKSAN
}

\author{
Adinda Fransisca Pongoh ${ }^{1)}$, Edwin de Queljoe ${ }^{1)}$, Henki Rotinsulu ${ }^{1)}$ \\ ${ }^{1)}$ Program Studi Farmasi FMIPA UNSRAT Manado, 95115
}

\begin{abstract}
This study aims to determine the antidiabetic activity of papaya flower ethanol extract (Carica papaya L.) against male white rats (Rattus norvegicus) induced by alloxan. This research is experimental. Fifteen rats were divided into 5 treatment groups, each group consisted of 3 rats. The first group was the negative control group given Aquades, the second group was positive control given Glibenklamid, the three groups were $200 \mathrm{mg}$ dose variation groups, four groups were $400 \mathrm{mg}$ dose variations, and the five groups were $800 \mathrm{mg}$ dose variations. Previously, rats were examined fasting blood glucose levels, then mice were induced by an alloxan dose of $120 \mathrm{mg} / \mathrm{kgBW}$ intraperitoneally. On the 3rd day blood glucose levels were examined and then treated according to groups for 7 days, measurement of blood glucose levels after the treatment was carried out once every 3 days namely day 3, day 7, and day 10. Data obtained were then analyzed statistically using SPSS, including normality test (Shapiro-Wilk), homogeneity test (Levene), ANOVA test (One way). The results of this study indicate that Papaya Flower (Carica papaya L.) Ethanol Extract can provide the best blood glucose level reduction effect at a dose of $800 \mathrm{mg}$.
\end{abstract}

\section{Keywords : Antidiabetic, Papaya Flower Extract (Carica papaya L.), Diabettes Mellitus, Male} White Rat (Rattus norvegicus), Aloxan.

\begin{abstract}
ABSTRAK
Penelitian ini bertujuan untuk mengetahui efektivitas Antidiabetik Ekstrak Etanol Bunga Pepaya (Carica papaya L.) Terhadap Tikus Putih Jantan (Rattus norvegicus) Yang Diinduksi Aloksan. Penelitian ini bersifat eksperimental. Sebanyak 15 ekor tikus dibagi ke dalam 5 kelompok perlakuan masing- masing kelompok terdiri dari 3 ekor tikus. Kelompok pertama kelompok Kontrol negatif yang diberikan Aquades, Kelompok kedua Kontrol Positif yang diberikan Glibenklamid, kelompok tiga kelompok variasi dosis 200 $\mathrm{mg}$, kelompok empat kelompok variasi dosis $400 \mathrm{mg}$, dan kelompok lima kelompok variasi dosis $800 \mathrm{mg}$. Sebelumnya tikus dilakukan pemeriksaan kadar glukosa darah puasa, selanjutnya tikus diinduksi Aloksan dosis $120 \mathrm{mg} / \mathrm{kgBB}$ secara intraperitoneal. Pada hari ke 3 diperiksa kadar Glukosa darah kemudian diberikan perlakuan sesuai kelompok selama 7 hari, pengukuran kadar glukosa darah setelah perlakuan dilakukan 3 hari sekali yaitu hari ke 3, hari ke 7, dan hari ke 10. Data yang diperoleh kemudian dianalisis secara statistik menggunakan SPSS, meliputi uji normalitas (Shapiro-Wilk), uji homogenitas (Levene), uji ANOVA (One way). Hasil penelitian ini menunjukkan bahwa Ekstrak Etanol Bunga Pepaya (Carica papaya L.) dapat memberikan efek penurunan kadar glukosa darah yang paling baik yaitu pada dosis 800 $\mathrm{mg}$.
\end{abstract}

Kata kunci : Antidiabetik, Ekstrak Bunga pepaya (Carica papaya L.), Diabettes Mellitus, Tikus Putih Jantan (Rattus norvegicus), Aloksan. 
PHARMACONJurnal Ilmiah Farmasi - UNSRAT Vol. 9 No. 1 FEBRUARI 2020 ISSN 2302 - 2493

\section{PENDAHULUAN}

Upaya kesehatan dengan memanfaatkan obat tradisional telah dikenal sejak dulu dan dilaksanakan jauh sebelum pelayanan kesehatan formal dengan obat-obat modern. Sampai saat ini masyarakat masih mengakui dan memanfaatkan pelayanan dan obat tradisional. Oleh karena itu sejalan dengan deklarasi Alma Alto dan anjuran Word Health Organization (WHO), dalam rangka peningkatan dan pelayanan kesehatan terhadap masyarakat, upaya kesehatan tradisional dengan obat tradisionalnya perlu dimanfaatkan sebaikbaiknya, dibina dan dikembangkan agar lebih berdaya guna (Subroto, 2006).

Diabetes merupakan sekelompok sindrom yang ditandai dengan hiperglikemia, perubahan metabolisme lipid, metabolisme karbohidrat, metabolisme protein dan peningkatan resiko komplikasi penyakit pembuluh darah (Gilman, 2007). Diabetes mellitus atau penyakit gula atau kencing manis adalah suatu gangguan kronis yang khususnya menyangkut metabolisme glukosa di dalam tubuh. Rata-rata 1,5-2\% dari penduduk dunia menderita diabetes yang bersifat menurun. Menurut data International Diabetes Federation (IDF) tahun 2015, Indonesia menempati urutan ke-7 penderita diabetes mellitus didunia, yaitu sebanyak 10,0 juta jiwa (International Diabetes Asociation, 2015).

Pada penderita diabetes, glukosa tidak dapat dikelola atau masuk kedalam sel untuk dimanfaatkan sebagai energi, sehingga kadar glukosa dalam darah meningkat. Perawatan untuk penderita diabetes dilakukan dengan terapi farmakologi dan non farmakologi. Untuk terapi farmakologi yaitu dengan menggunakan obat-obatan meliputi golongan sulfonilurea, biguanid, tiazolidindion, penghambat aglukosidase, serta pemberian insulin (Sukandar et al., 2013). Sedangkan untuk terapi non farmakologi dengan cara menjaga kadar glukosa darah, pemeriksaan rutin kadar glukosa darah dan urin, mengatur pola makan dan diet serta berolah raga yang teratur (Taylor, 2009). Namun pemberian obat-obatan pada terapi farmakologi tersebut memiliki beberapa efek samping serta harga yang tidak murah, sehingga pemilihan pengobatan alternatif dalam hal ini penggunaan obat alami perlu dipertimbangkan. Sebagai salah satu alternatif adalah dengan melakukan penelitian tentang obat tradisional yang mempunyai efek hipoglikemia. Pada tahun 1980 WHO merekomendasikan agar dilakukan penelitian terhadap tanaman yang memiliki efek menurunkan kadar gula darah karena pemakaian obat modern kurang aman (Kumar et al., 2005).

Tanaman pepaya (Carica papaya L.) merupakan tanaman yang secara keseluruhan memiliki banyak manfaat, baik akar, daun, bunga, buah maupun bijinya (Hariana, 2013). Secara empiris, bunga pepaya biasanya direbus dan digunakan untuk obat diabetes mellitus (kencing manis), memperbaiki nafsu makan, membersihkan darah, dan obat sakit kuning (Khomsan, 2009). Bunga 
pepaya mengandung flavonoid, tannin, steroidtriterpenoid, dan karbohidrat (Indrawati, et al, 2002).

\section{METODOLOGI PENELITIAN}

Penelitian ini menggunakan jenis penelitian eksperimental. Penelitian ini menggunakan hewan uji tikus putih jantan (Rattus norvegicus) serta obat Glibenklamid sebagai pembanding.

Alat yang digunakan, yaitu : Timbangan analitik, blender, oven, ayakan biasa, kertas saring, gelas ukur, aluminium foil, Erlenmeyer, toples, rotary evaporator, sonde, lumpang dan alu, jarum dan dispo, kandang hewan, kapas, corong, gunting, alat pengukur glukosa darah (Easy Touch GCU).

Bahan yang digunakan, yaitu : Bunga pepaya (Carica papaya), aloksan, etanol 96\%, glibenklamid, makanan standar pellet, aquades, tikus putih jantan (Rattus norvegicus), alkohol.

\section{Pengambilan dan Pengumpulan Sampel}

Sampel bunga papaya (Carica papaya $\mathrm{L}$.) diambil dan dikumpulkan dari perkebunan di daerah sekitar Desa Kembes Satu, Kecamatan Tombulu, Kabupaten Minahasa, Provinsi Sulawesi Utara.

\section{Pembuatan Ekstrak Etanol Bunga Pepaya}

Bunga pepaya dikeringkan dengan cara dijemur dibawah sinar matahari dengan dilindungi kain tipis hitam untuk mencegah kontaminasi partikel dari luar. Setelah didapatkan 300 gram bunga pepaya kering, dilakukan penghalusan dengan cara diblender hingga menjadi bubukan dan diayak menggunakan ayakan biasa. Setelah halus, serbuk bunga pepaya direndam menggunakan $1500 \mathrm{~mL}$ etanol 96\% selama 3 hari. Rendaman bunga pepaya disaring menggunakan kertas saring dalam Erlenmeyer $1000 \mathrm{~mL}$ kemudian didapatkan filtrat 1 , sisa dari ekstrak tersebut dimaserasi kembali menggunakan $600 \mathrm{~mL}$ etanol $96 \%$ selama 2 hari. Rendaman tersebut disaring menggunakan kertas saring sehingga didapatkan Filtrat 2. Kemudian Filtrat 1 dan 2 dievaporasi pada suhu $40^{\circ} \mathrm{C}$ selama 5 jam hingga diperoleh ekstrak kental.

\section{Pembuatan Larutan Ekstrak}

Larutan ekstrak dibuat berdasarkan dosis dengan jumlah ekstrak dan pelarut yang sesuai dengan perhitungan dosis yang telah ditentukan yaitu :

a. Dosis I $200 \mathrm{mg}$

$200 \mathrm{mg} \times 0,018=3,6 \mathrm{mg}$.

Sebanyak 3,6 mg ekstrak dilarutkan ke dalam aquades sebanyak $1 \mathrm{~mL}$.

b. Dosis II $400 \mathrm{mg}$

$400 \mathrm{mg} \times 0,018=7,2 \mathrm{mg}$

Sebanyak 7,2 mg ekstrak dilarutkan

ke dalam aquades sebanyak $1 \mathrm{~mL}$.

c. Dosis III $800 \mathrm{mg}$

$800 \mathrm{mg} \times 0,018=14,4 \mathrm{mg}$

Sebanyak 14,4 mg ekstrak dilarutkan ke dalam aquades sebanyak $1 \mathrm{~mL}$.

Masing-masing larutan yang telah siap, diberikan pada tikus kelompok perlakuan sesuai dengan dosis yang telah ditentukan. Larutan diberikan dengan cara oral atau pencekokan pada hewan uji. Pencekokan dilakukan dengan menggunakan sonde. 


\section{Pembuatan Larutan Glibenklamid} Glibenklamid $\quad 5 \quad \mathrm{mg}$ sebagai kontrol positif. Dosis pemberian glibenklamid pada tikus dikonversikan berdasarkan perhitungan konversi dosis. Glibenklamid diberikan dengan dosis untuk manusia : $5 \mathrm{mg}$, untuk tikus konversi dosis adalah : $0,018 \times 5 \mathrm{mg}=$ $0,09 \mathrm{mg} / 200 \mathrm{gr} \mathrm{BB}$ tikus.

Sebanyak $0,09 \mathrm{mg}$ glibenklamid dilarutkan ke dalam aquades sebanyak 1 $\mathrm{mL}$ Larutan glibenklamid yang telah siap, diberikan secara oral ke hewan uji.

\section{Pembuatan Larutan Aloksan}

Larutan aloksan dibuat berdasarkan dosis yang telah ditentukan yaitu sebanyak $24 \mathrm{mg}$ bubuk aloksan dilarutkan dalam aquades sebanyak $1 \mathrm{~mL}$.

\section{Rancangan Penelitian}

Hewan uji dipilih sebanyak 15 ekor tikus putih jantan secara acak dan dibagi dalam 5 kelompok dengan jumlah masing-masing kelompok terdiri dari 3 ekor.

Tabel 1. Kelompok Perlakuan Uji

\begin{tabular}{|c|c|c|}
\hline Keloaipok Tikas & Jamblah Tikas & Perlakman \\
\hline Kontrol Krgatif & 3 & Dikerikan aquades \\
\hline Kontral Poritif & 3 & Dikerikan larutan Glibealdanid 0,09 mg \\
\hline Dosis I & 3 & Diberilan ekatrak Bunga Pepaya 3,5 mg \\
\hline Desk II & 3 & Dibenkan ekstrak Bung Pepaya 7,2 mg \\
\hline Dosis III & 3 & Diberikan ekstrak Bunga Pepaya $14,4 \mathrm{mg}$ \\
\hline
\end{tabular}

Penyiapan dan Perlakuan Hewan Uji

Sebanyak 15 ekor tikus putih jantan galur wistar (Rattus novergicus) diletakkan di dalam kandang yang dibagi menjadi 3 ekor tikus dalam satu kandang. Dasar kandang dilapisi dengan serbuk kayu setebal 1-2 $\mathrm{cm}$ dan diganti setiap 3 hari untuk mencegah infeksi yang terjadi akibat kotoran. Kandang ditempatkan dalam suhu kamar alamiah yaitu $27 \pm 3^{\circ} \mathrm{C}$ dan kelembaban udara dibiarkan pada kisaran alamiah yaitu $60-85 \%$, serta cahaya menggunakan sinar matahari tidak langsung. Makanan yang diberikan pada tikus adalah pelet komersial dan minuman yang diberikan adalah air putih yang diletakkan dalam botol. Makanan dan minuman diberikan secukupnya dalam wadah terpisah dan diganti setiap hari.

Tikus sejumlah 15 ekor dibagi menjadi 5 kelompok dengan masingmasing kelompok terdiri atas 3 ekor tikus. Kelompok I adalah kelompok kontrol negatif yang diberi aquades. Kelompok II adalah kelompok kontrol positif yang diberikan glibenklamid. Kelompok III adalah kelompok perlakuan yang diberi dosis $3,6 \mathrm{mg} / \mathrm{mL}$. Kelompok IV adalah kelompok perlakuan yang diberi dosis 7,2 $\mathrm{mg} / \mathrm{mL}$. Kelompok V adalah kelompok perlakuan yang diberi dosis $14,4 \mathrm{mg} / \mathrm{mL}$.

Dilakukan pemeriksaan gula darah awal pada hari ke-0, kemudian setelah pemeriksaan kadar glukosa darah tikus normal, tikus dipuasakan selama 8 jam.

Tikus diinduksi aloksan secara intra peritoneal dengan jumlah dosis sebanyak $24 \mathrm{mg}$ pada hari ke 1, dan diperiksa gula darah diabetik pada hari ke 3. Tikus dinyatakan hiperglikemia apabila kadar glukosa darah $\geq 135 \mathrm{mg} / \mathrm{dL}$ (Prameswari \& Widjanarko, 2014). 


\section{Pengaplikasian Ekstrak}

Ekstrak bunga pepaya diberikan secara per oral satu kali sehari setelah 3 hari pemberian induksi.

Pada kelompok I diberi aquades. Pada kelompok II diberi glibenklamid 0,09 $\mathrm{mg} / \mathrm{mL}$.

Pada kelompok III diberi ekstrak bunga pepaya $3,6 \mathrm{mg} / \mathrm{mL}$. Pada kelompok IV diberi ekstrak bunga pepaya $7,2 \mathrm{mg} / \mathrm{mL}$. Pada kelompok $\mathrm{V}$ diberi ekstrak bunga pepaya $14,4 \mathrm{mg} / \mathrm{mL}$.

\section{Pengambilan Darah}

Pengambilan darah dilakukan melalui vena pada ekor tikus. Pengambilan darah dilakukan sebanyak 4 kali dengan ketentuan sebagai berikut :
a. Hari ke-0 : pemeriksaan gula darah awal dilakukan sebelum tikus diinduksi aloksan
b. Hari ke-3 : pemeriksaan gula darah dilakukan pada hari ke 3 setelah diinduksi aloksan dilakukan pada hari ke 3 pemberian ekstrak
c. Hari ke-7 : pemeriksaan gula darah
d. Hari ke-10 : pemeriksaan gula darah dilakukan pada hari ke 7 pemberian ekstrak

\section{Analisis Data}

Metode analisis data yang digunakan dalam penelitian ini yaitu metode Analysis of Variance (ANOVA) one-way, dengan taraf kepercayaan $95 \%$ dan tingkat signifikansi (tingkat kesalahan $) 5 \% \quad(\alpha=0,05)$. Metode ANOVA one way digunakan untuk mengetahui ada tidaknya pengaruh ekstrak bunga pepaya terhadap penurunan kadar glukosa darah pada tikus. Selain itu, ANOVA pada penelitian ini juga digunakan untuk mengetahui ada tidaknya perbedaan secara bermakna efektivitas ekstrak dan senyawa pembanding glibenklamid dalam menurunkan kadar glukosa darah. Analisis data secara ANOVA menggunakan aplikasi Statistical Product and Service Solution (SPSS) Versi 23.0 for windows 10 .

\section{HASIL DAN PEMBAHASAN}

Tanaman bunga pepaya awalnya hanya dikenal sebagai makanan atau sayuran yang biasanya dinikmati oleh masyarakat daerah yang terlebih khusus di daerah Minahasa. Tanaman ini memiliki rasa yang pahit, dengan ukuran yang kecil dan tumbuh pada pepohonan pepaya.

Identifikasi tanaman dilakukan untuk memastikan tanaman yang diteliti sesuai dengan pustaka tanaman bunga pepaya dan tidak terjadi kesalahan dalam pengambilan sampel. Dan melalui identifikasi tanaman ini, jelas bahwa tanaman yang digunakan dalam penelitian ini adalah benar-benar tanaman bunga pepaya.

Pada penelitian ini digunakan ekstraksi dengan metode maserasi. Metode ini dipilih karena sederhana dan mudah serta sangat cocok dengan sampel yang tidak tahan terhadap proses pemanasan seperti bunga pepaya. Maserasi dilakukan untuk menarik zat-zat yang terkandung dalam sampel dan 
dengan menggunakan pelarut etanol $96 \%$, karena flavonoid yang terkandung dalam bunga pepaya bersifat polar, sehingga diperlukan pelarut yang bersifat polar juga. Hal ini sesuai dengan hukum like disolve like (Markham, 1988).

Dari berat basah 6500 gram sampel bunga pepaya dikeringkan, hal ini bertujuan untuk memperbesar luas permukaan sampel sehingga kontak antara cairan penyari dan sampel lebih besar sehingga memudahkan penyarian komponen kimia yang terdapat di dalam sampel, kemudian sampel kering diblender dan didapatkan 300 gram serbuk bunga pepaya, setelah itu sampel dimaserasi dengan etanol 96\% selama 5 hari kemudian diuapkan dalam oven pada suhu $40^{\circ} \mathrm{C}$, tujuannya untuk memperoleh ekstrak kental dari hasil maserasi, sehingga diperoleh ekstrak kental sebanyak 24,63 gram.

Dalam penelitian ini digunakan hewan uji, yaitu tikus putih jantan sebanyak 15 ekor dengan berat badan rata-rata 200 gram dan berusia sekitar 3 bulan, serta dalam keadaan sehat (tidak diabetes). Hewan uji dibagi dalam 5 kelompok perlakuan dan dipilih secara acak. Kelompok pertama merupakan kontrol negatif dimana tikus diinduksi aloksan, setelah hiperglikemik tikus ini hanya diberi aquades. Kelompok kedua merupakan kontrol positif dimana tikus diinduksi aloksan dan setelah tikus hiperglikemik diberi glibenklamid sebagai obat antidiabetes golongan sulfonilurea. Pada tiga kelompok berikutnya, tikus diinduksi aloksan dan setelah mengalami hiperglikemik diberikan ekstrak bunga pepaya dengan dosis yang berbeda-beda. Dosis I yaitu ekstrak bunga pepaya dosis $200 \mathrm{mg}$, Dosis II yaitu ekstrak bunga pepaya dosis 400 mg, dan Dosis III yaitu ekstrak bunga pepaya dengan dosis $800 \mathrm{mg}$. Namun, sebelum diinduksi tikus dipuasakan terlebih dahulu dengan tetap diberi minum.

Pada penelitian ini, semua hewan uji diinduksi dengan aloksan. Aloksan mempunyai kemampuan merusak sel beta pankreas (Yuriska, 2009). Pengukuran kadar glukosa darah setelah diinduksi aloksan dilakukan pada hari ketiga. Pemeriksaan kadar glukosa darah tikus menggunakan glucometer (Easy Touch GCU). Pemberian aloksan menyebabkan kadar glukosa darah tikus meningkat signifikan.

Tabel 2. Rata-rata Kadar Glukosa setelah Diinduksi Aloksan

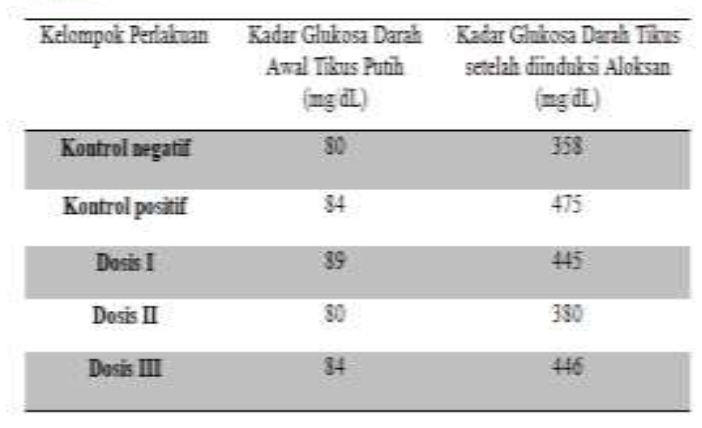

Pada tabel di atas dapat dilihat bahwa semua tikus kelompok perlakuan yang diinduksi aloksan mengalami kenaikan kadar glukosa darah pada hari ke-3 setelah penginduksian secara intraperitoneal. Kenaikan kadar glukosa darah berbeda-beda sesuai dengan metabolisme tubuh. Dosis aloksan yang diberikan yaitu dosis $120 \mathrm{mg} / \mathrm{kgBB}$ tikus. 
Semua kelompok yang telah diinduksi aloksan diharapkan memiliki kadar glukosa darah yang tidak berbeda secara signifikan sebelum diberikan perlakuan, agar dapat diamati efek penurunan kadar glukosa darah setelah perlakuan pada semua kelompok.

Setelah tikus mengalami hiperglikemik, maka semua kelompok diberi perlakuan selama 7 hari. Baik kontrol negatif, kontrol positif, maupun perlakuan ekstrak masing-masing dosis. Dan dari hasil pemeriksaan kadar glukosa darah pada hari ke-3, ke-7 dan ke-10 didapatkan hasil bahwa kadar glukosa darah terus meningkat pada kontrol negatif, hal ini disebabkan karena aquades tidak memiliki efek untuk menurunkan glukosa darah atau hanya bersifat netral. Peningkatan glukosa darah ini disebabkan karena efek aloksan masih bekerja pada pengukuran kadar glukosa akhir. Penurunan kadar glukosa darah yang signifikan terjadi pada kelompok kontrol positif (glibenklamid), perlakuan dosis $200 \mathrm{mg} / \mathrm{kgBB}$, dosis $400 \mathrm{mg} / \mathrm{kgBB}$, dan dosis $800 \mathrm{mg} / \mathrm{kgBB}$. Kelompok kontrol positif memberikan efek penurunan yang signifikan.

Menurut Suherman (2007), penurunan kadar glukosa darah ini disebabkan oleh sifat farmakodinamik glibenklamid yang merangsang sel beta pankreas dalam mensekresi insulin meskipun sel beta pankreas telah dirusak dengan pemberian aloksan, tetapi kerusakan ini bersifat parsial sehingga terdapat sel beta pankreas yang masih dapat mensekresi insulin dan menjaga kadar euglikemia.
Penurunan kadar glukosa darah terjadi kemungkinan karena kandungan flavonoid dalam tanaman Bunga pepaya ini (Soedibyo, 1998). Flavonoid diduga bekerja dengan cara meregenerasi dan merangsang pelepasan insulin oleh sel beta pankreas (Dheer dan Bhatnagar, 2010). Kerja dari flavonoid inilah yang menyebabkan adanya efek antidiabetik ekstrak bunga pepaya ini. Flavonoid banyak ditemukan pada bagian batang, akar, bunga pada suatu tanaman. Flavonoid yang terkandung di dalam bunga pepaya ini memiliki kemampuan dalam menghambat enzim glukosidase dan alfa amilase yang berfungsi dalam memecah karbohidrat menjadi monosakarida. Dengan penghambatan tersebut maka pemecahan karbohidrat menjadi monosakarida menjadi gagal sehingga tidak terdapat glukosa (monosakarida) yang dapat diserap oleh usus dan terjadilah penurunan kadar glukosa dalam darah.

Tabel 3. Rata-rata Kadar Glukosa Darah setelah Perlakuan

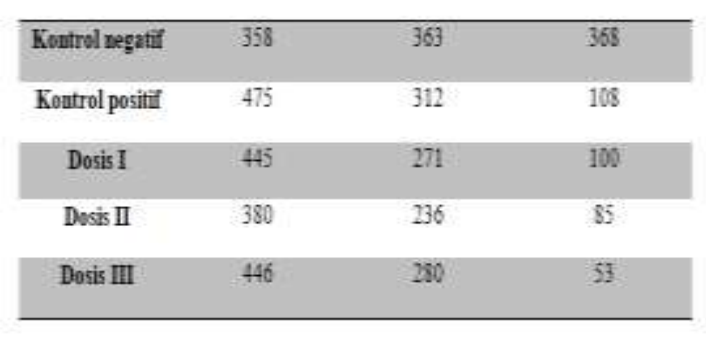

Pada tabel di atas dapat dilihat bahwa setelah diberikan perlakuan, semua kelompok perlakuan tikus mengalami perubahan kadar glukosa darah. hal ini disebabkan terjadinya metabolisme di dalam tubuh hewan uji. Dan rata-rata mengalami penurunan baik pemberian 
ekstrak maupun glibenklamid (kontrol positif), namun pada pemberian aquades (kontrol negatif) tidak terjadi penurunan melainkan terjadi kenaikan kadar glukosa darah hingga tikus melemah dan akhirnya mati. Penurunan kadar glukosa darah, diperiksa pada hari ke-3, ke-7, ke-10 setelah tikus dinyatakan hiperglikemik. Pada dosis ekstrak 200mg memiliki nilai penurunan yang paling mendekati dengan glibenklamid sebagai kontrol positif, kemudian diikuti dengan dosis 400mg dan dosis 800mg. Pada ketiga dosis ekstrak ini menunjukkan adanya penurunan kadar glukosa darah. Potensi efek penurunan kadar glukosa dilihat dari rata-rata penurunan setiap dosis perlakuan dengan membandingkan kontrol positif (glibenklamid). Dari hasil perbandingan inilah maka dapat dikatakan bahwa dosis yang paling efektif dalam menurunkan kadar glukosa darah yaitu pada dosis $800 \mathrm{mg}$.

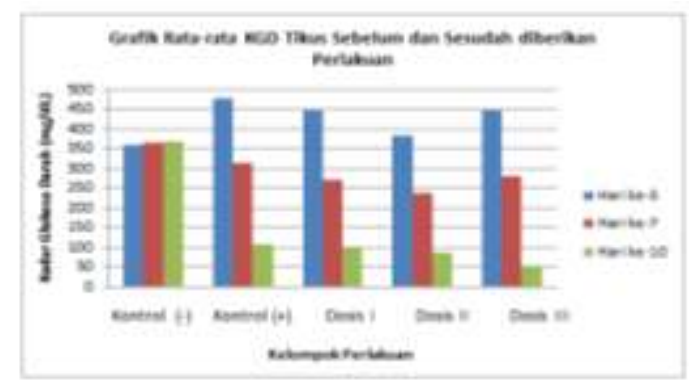

Gambar 1. Grafik Rata-rata Kadar Glukosa Darah (KGD) Tikus Sebelum dan Sesudah diberikan Perlakuan

Pada grafik di atas, dapat dilihat bahwa glibenklamid memiliki efek yang sama dengan dosis I. Tujuannya dilakukan perbandingan ini untuk mengetahui efektivitas dosis perlakuan dibandingkan dengan efektivitas kontrol positif yaitu glibenklamid.

Selanjutnya, data atau hasil yang diperoleh dilakukan analisis statistik melalui uji SPSS untuk mengetahui perbedaan rata-rata penurunan kadar glukosa darah pada tikus antar kelompok perlakuan.

Hasil uji ANOVA pada kelompok yang telah mengalami hiperglikemik menunjukan tidak ada perbedaan kadar glukosa darah yang bermakna antar kelompok perlakuan. Hal ini dilihat pada nilai Signifikan $\mathrm{p}>0.05$ sehingga Ho diterima.

Sebelum melakukan uji One way Anova maka dilakukan uji normalitas data dan uji homogenitas (Sopiyudin,2015). Data yang diuji ini berjumlah $<50$ data maka menggunakan uji Shapiro-Wilk. Uji normalitas data dari kelompok tikus setelah diinduksi aloksan didapatkan nilai sig > 0,05, maka data terdistribusi normal . Uji homogenitas dari data post aloksan dan akhir didapatkan nilai $\mathrm{p}>0,05$ maka varian data bersifat homogen. Pada uji ANOVA didapatkan nilai $\mathrm{p}=0,875$ karena nilai $\mathrm{p}$ $>0,05$ sehingga dapat disimpulkan bahwa dalam perlakuan tidak terdapat perbedaan yang nyata setelah diinduksi aloksan ketika diberikan ekstrak bunga pepaya (Carica papaya L.).

\section{KESIMPULAN}

Kesimpulan yang didapat dari hasil penelitian ini, yaitu ekstrak etanol bunga pepaya pada dosis $800 \mathrm{mg}$ 
merupakan dosis yang paling baik dalam menurunkan kadar glukosa darah dibandingkan dosis $400 \mathrm{mg}$ dan dosis 200 mg. Oleh karena itu, dapat disimpulkan bahwa ekstrak tersebut memiliki efek sebagai antidiabetes.

\section{SARAN}

Perlu dilakukan penelitian lebih lanjut dengan menggunakan metode yang berbeda untuk mengetahui dosis yang tepat dan optimal dari ekstrak etanol bunga pepaya yang berkhasiat menurunkan kadar glukosa darah atau untuk digunakan sebagai antidiabetes dengan menggunakan jenis penginduksi yang lain.

\section{DAFTAR PUSTAKA}

Dheer R. dan Bhatnagar P., 2010. A study of the Antidiabetic Activity of Barleria prionitis Linn. Indian Journal of Pharmacology. Vol 42 (2): 70-3.

Gilman, A. G., 2007, Goodman \& Gilman. Dasar Farmakologi Terapi, diterjemahkan oleh Tim Alih Bahasa Sekolah Farmasi ITB, Edisi $X$, 877. Jakarta: Penerbit Buku Kedokteran. EGC.

Indrawati $\mathrm{Y}$, Kosasih $\mathrm{P}$, Soediro S, Asep G.S. 2002. Telaah Fitokimia Bunga Pepaya Gantung (Carica papaya L.) dan Uji Aktivitas Antioksidannya. Sekolah Farmasi ITB. http://bahanalam.fa.itb.ac.id. Diakses tanggal 23 Mei 2019.

International Diabetes Asociation. 2015. IDF Diabetes Atlas Seven Edition
15. Diakses pada tanggal 23 mei 2019 dari www.eatlas.idf.org.

Khomsan, Ali. 2009. Rahasia Sehat Dengan Makanan Berkhasiat. Jakarta: Kompas Media Nusantara.

Kumar, R. 2005. Research methodology: Step by step guide for beginners (2nd ed.). London: SAGE Publications Ltd.

Markham, K.R., 1988, Cara Mengidentifikasi Flavonoid. Diterjemahkan oleh Padmawinata, Bandung, Penerbit ITB, hal 15.

Prameswari, O. M., dan Widjanarko, S. B. 2014. Uji Efek Ekstrak Air Daun Pandan Wangi Terhadap Penurunan Kadar Glukosa Darah Dan Histopatologi Tikus Diabetes Mellitus. Jurnal Pangan dan Agroindustri. Vol.2 No.2 p.16-27.

Soedibyo B. R. A. M., 1998. Alam Sumber Kesehatan Manfaat dan Kegunaan. Jakarta: Balai Pustaka. pp : 81.

Subroto. 2006. Penatalaksanaan Diabetes. http://www.google.com. Diakses tanggal 23 Mei 2019.

Suherman S. K., 2007. Insulin dan Antidiabetik Oral. Dalam : Gunawan, S.G. Farmakologi dan Terapi. Edisi 5. Jakarta: Balai Penerbit FKUI. pp: 485; 489- 93.

Sukandar Elin Yulinah, Andrajati Retnosari, Sigit Joseph, Adnyana I Ketut, Setiadi Adji Prayitno, 
PHARMACONJurnal Ilmiah Farmasi - UNSRAT Vol. 9 No. 1 FEBRUARI 2020 ISSN 2302 - 2493
Kusnandar.
2013.
Iso
Farmakoterapi I. Jakarta: Isfi
Penerbitan.

Taylor, Barbara. 2009. Diabetes Tak Bikin Lemes. Yogyakarta: Paradigma Indonesia.

WHO. 1999. Definition, Diagnosis, and Classification of Diabetes Mellitus and its Complications. World Health Organization Department of Noncommunicable Disease Surveillance. Geneva. Page 1-65. 